\title{
Three Approaches to Gender Equity in Science Education
}

\begin{abstract}
In this article I use feminist critique of science as a point of departure to discuss different understandings of how sex/gender impacts on pupils' approaches to science education. I construct a theoretical framework that shows three different approaches to increase gender equity in science education. Each approach is grounded in a distinct understanding of how sex/gender impacts pupils'engagement in science education. The analytical frame that is developed thereby represents descriptions of three alternative ways to address gender inequity in science education. The framework shows how different understandings of how sex/gender impact on pupils' engagement in science education require distinct initiatives to increase gender equity. The framework can be used in the planning and analysis of how gender initiatives work to address gender inequity in science education.
\end{abstract}

\section{USING FEMINIST CRITIQUE OF SCIENCE TO ANALYZE AND PLAN EDUCATION INITIATIVES}

All initiatives that address gender inequity in science education reflect a certain understanding of how the pupils' sex/gender impact on how they learn and engage in science education. I use the term sex to represent biological sex and gender to represent social sex (for further description of this distinction, see Sinnes, 2005). Initiatives may for instance assume that girls and boys have exactly the same abilities to succeed on equal terms in science subjects, and that gender inequities in these subjects are caused by discriminating attitudes towards one of the two sexes. Other initiatives might assume that girls and boys are different and that these differences need to be addressed and catered for in order to reduce the gender differences in science education. Although all initiatives reflect certain understandings of how girls and boys may differ and how these differences might impact on how they engage in science education, these understandings are seldom formulated explicitly by gender initiatives. By not being explicit, and perhaps even not conscious about what understanding the initiative is actually situated within, such initiatives will often develop recommendations that might be inconsistent in terms of their suggestions to what needs to be done to secure gender equity.

Few have attempted to apply feminist theories and critiques of science to analyze and plan gender and science education initiatives. There is therefore limited amount of literature available that discusses the implications and relevance of this theory for gender and science education reform programs. The people who have utilized feminist theory as a resource in science education (see for 
instance Barton, 1998; Brickhouse, 2001; Howes, 2002; Rosser,1990; Scantlebury, 1998; Shulman, 2001; Whatley, 1988; Ødegaard, 2001) have used this theory mainly to position themselves, and to outline the implications of their positions for gender and science education reform. Eisenhart and Finkel (2001) is the only publication I have come across that attempts to use feminist theory to analyse education reform programmes in science education. Barton (1998) has analysed what gender initiatives in science education have followed historically from the different "waves" of feminist critique of science. Presenting feminist critiques of science for the purpose of understanding various approaches to gender equity in science education is therefore an exploratory task.

In my reading of feminist critiques of science, I have searched for different perspectives regarding the impact of sex/gender on how scientists engage in science inquiry. I have used these perspectives as a point of departure to reflect on how sex/gender impacts on how male and female pupils engage in science education. Based on different understandings of how sex/gender might impact on pupils' engagement in science education, I suggest three alternative approaches that initiatives might choose to secure increased gender equity in science education; a gender neutral, a female friendly and a gender sensitive approach. These concepts are widely used within literature on gender issues in science education. Often, however, they are used invariably and without a consistent meaning. In this article I show that each approach can in fact be seen to represent a distinct understanding of how sex/gender impacts on pupils' engagement in science education and hence represent different understandings of what actions are needed in order to increase gender equity in science education.

\section{CONSTRUCTING AN ANALYTICAL FRAMEWORK}

Feminist critiques of science have discussed science education only to a very little extent and they do not explicitly discuss how sex/gender impacts the learning of science. In constructing this analytical framework, I use the same perspectives found on the impact of sex/gender regarding scientists' engagement in science inquiry to reflect upon how children engage with science in school. The understandings of how sex/gender impacts on a scientist's approach to science can not necessarily be directly transmitted to the understanding of how sex/gender impacts pupils' engagement in science in schools. Therefore I use feminist critique of science only as a resource to detect different perspectives on how males and females can be seen to differ in their engagement in science. I use these perspectives as a source to suggest possible understandings of how girls and boys may differ in their engagement in science education.

If one, on the one hand, makes use of feminist theory solely to determine alternative ways of perceiving how male and female pupils differ in their approach to science education, one will deduce one set of consequences for science education reform programs. Such consequences would be designed to accommodate our analysis of how sex/gender is seen to impact on one's approach to science education. If, on the other hand, science education initiatives should be planned according to the understanding that male and female researchers would advance different kinds of scientific knowledge, this would also challenge what image of the nature of science should be reflected through science education.

In my presentation of what I see as consequences for science education reform programs of the various feminist criticisms, I have incorporated the consequences of each criticism for the organization and planning of science education and also for the image it reflects of the nature of science. Several science educators do, however, see these two factors as separate (Sinnes, 2005).

The described approaches represent prototypes. Most gender initiatives will carry out a mix of the recommendations described in each approach. Displaying the recommendations according to what perception they reflect of the impact of sex/gender on pupils' engagement in science makes it possible to visualize that different recommendations do in fact reflect different understandings 
of how sex/gender impact on pupils' engagement in science education. By analyzing gender initiatives according to this framework it therefore might be possible to unravel inconsistencies and contradictions in recommendations made by such initiatives.

\section{Alternative 1: Girls and boys are equal in their engagement in science education}

The first understanding of how sex/gender might impact on pupils' engagement in science education I discuss is that there is no difference in how males and females engage in science education. This understanding is expressed by feminist critics that are here described as equality feminists.

What I describe as equality feminist perspectives include understandings of males and females as, in principle, equal in their approach to science. Positions focusing on the similarities between males' and females' approaches to scientific inquiry have in feminist literature been referred to as "feminist empiricism" (Harding, 1986), "liberal feminist critique" (Howes, 2002; Keller, 1987) and "first wave feminism" (Barton, 1998). What I see as common to these perspectives is an understanding that females in principle will produce exactly the same scientific knowledge as males provided that sufficient rigueur is undertaken in scientific inquiry. I therefore find the term equality feminism as suited to cover the various understandings implicit in this position. Equality feminists recognize that females have been kept away from science because of political and social forces external to science (Howes, 2002).

The critique of science pursued by equality feminists was developed mainly as a critique of unfair employment practices within sciences without accusing scientific knowledge of being inherently masculine (Harding, 1986; Keller, 1985, 1987). The basic assumption within this critique is that men and women are equal and should therefore have equal opportunities in the research society. This would benefit women as they would have their possibilities and equity rights extended. It would also benefit the society in general as there would be more women contributing to the development of scientific knowledge. The ability of creating valid scientific knowledge is, according to adherents to this position, not determined by gender or sex but by one's scientific training. Women and men are thus equally capable of contributing to scientific development. If any sexual bias can be detected in science this is, according to the feminist empiricist, a consequence of insufficient rigour in the scientific methods employed, not because the scientists are males (Harding, 1992). Scientific knowledge is not regarded as discriminating against females since any competent observer in scientifically controlled observations will understand phenomena in precisely the same way as another: "To put this point another way, it is not supposed to make any difference to the 'goodness' of the research if the researcher is Chinese or British, black or white, a woman or a man. Scientific methods are supposed to be powerful enough to eliminate any social biases that might find their way into scientific hypothesis because of the social identity of the scientist"(ibid., p. 60). Some people adhering to this type of feminism would acknowledge the impact of the researcher's sex/gender on the research priorities, while the actual science inquiry would not be affected by the sex/gender of the researcher.

Irrespectively of how one looks at why science might benefit from having more females involved, what I consider to be the key idea implicit in equality feminism, is that the sex/gender of the researcher should not impact on the production of scientific knowledge. Stringent rules guiding high quality scientific inquiry would remove possible biases caused by males having a different focus. Scientific knowledge is considered to be objective and value free, and there is consequently nothing masculine about high quality scientific knowledge that would discriminate against females. According to Barton (1998) and Harding (1986) feminist voices here referred to as equality feminists have played a major role in eliminating the formal barriers against women's equality in science, mathematics and engineering by advocating females' abilities to advance science inquiry on equal terms as males. Although this theoretical position is said to have been the dominating 
feminist philosophy of science in the 1960s and 70s (Barton, 1998), several people engaged in questions of females and science still adhere to this understanding of the role of females in science. Howes (2002) asserts that most initiatives currently addressing gender issues in science education operates under the premises of equality feminism. Such initiatives would seek to recruit more females to science without challenging possible masculinities implicit in scientific knowledge.

I will now turn to discuss what I see as possible implications of this position for a science education designed to increase gender equity. The way I interpret the consequences of this position for science education initiatives aiming at gender equity, the key to improving female participation in science would be to address and change the political, educational and social factors that keep females away from science.

Initiatives that build on the assumption that females and males are equal in their approach to science, and that inequality in science and science education is caused by political, educational and social factors external to science, would be expected to focus on removing these external obstacles. In a gender and science reform program operating under the premises of equality feminism, I would therefore expect a central goal to be to give girls and boys exactly the same opportunities and challenges. It would be important to avoid discrimination caused by placing girls and boys in traditional gendered roles. Girls and boys should be encouraged to develop similarly without emphasizing their sex.

In order to avoid discriminatory practices of males and females, society should, particularly in traditional and patriarchal societies, be sensitized to understand the equal ability of males and females to become scientists and engage in science. This could be done through campaigns where female role models who had succeeded on equal terms as men in scientific positions were used to visualize the equal ability of females to pursue scientific careers. Policies should be implemented that would make it impossible to discriminate against girls' opportunity for schooling.

A gender reform program in science education operating under the premises of equality feminism would be expected to focus on removing all gender biases and practices discriminating against females. In this regard, it would be important to develop gender neutral education material. This could be done either by removing all references to sex, refer equally to the two sexes, or challenge traditional gender roles in texts and illustrations. It would also be important to avoid pictures that for example portray males in active and females in passive positions. Curricula and teaching materials should accommodate girls' and boys' experiences and interests equally without emphasizing one sex over the other. Great care should, however, be taken in curriculum and teaching material development not to convey stereotyped images of males and females.

In a science education inspired by equality feminism, science teachers should play an active role in the avoidance of treating males and females differently. Teachers should give equal attention to boys and girls in class. They should also not say anything that could be understood as discriminatory to girls and boys, in the sense of giving the impression that males and females are different in their engagement in science and science education. Ideally, there should be an equal number of male and female science teachers to underline the point that males and females are equally capable of pursuing a career in science education.

Science curricula and examinations should be developed to be gender neutral and equally relevant to boys and girls. Science education operating under the premises of equality feminism would tend to be a science education that could be described as "gender neutral science education". The characteristics I suggest of a gender neutral science education are outlined in Table 1. 


\section{Alternative 2: Girls and boys are different in their engagement in science education}

The next alternative I will discuss is that there is in fact a difference between girls and boys in terms of how they engage in science education. Either because of biological differences or since society is not gender neutral, girls and boys have developed differently, developed different interests and attitudes and these differences will impact on how they engage in science education. Feminists claiming this position are here labeled difference feminists. Difference feminists claim that either by nature and/or through nurture, women have developed what society refers to as "feminine" or "female" characteristics and those women's particular skills should be recognized and acknowledged for their own values (Nash, 2000). They see the notion of "equality" as problematic because it is seen to reproduce a male norm. Difference feminists have criticized feminists claiming that males and females are equal in their approach to science for producing a "patriarchal masquerade of neutrality" (Franklin, 2000, p. 434) and for valuing characteristics associated with masculinity higher than feminine or female characteristics (Tong, 2000). Difference feminists argue that scientific knowledge, its processes and priorities are influenced by the identity of the researcher and that whether the researcher is a male or a female is of seminal importance. They claim that science has been developed historically without the contribution of women and people from non-western cultures. This has made scientific knowledge and knowledge production "masculine", "western" and hence unwelcoming and discriminating to women (Harding, 1998; Rosser, 1990). Since science has been developed mainly by western males, it lacks certain "feminine" attributes that would widen and improve the practices and effects of science, particularly its social impact. The assumption is made that scientific inquiry is still very influenced by the positivist tradition of the 17th century. Difference feminists claim that even though the scientific ideology, its values, goals and assumptions has expanded after the 17th century, the assumptions of the essential nature of science; that scientific facts are grounded in sound scientific theory largely free of personal, social and cultural values, has persisted (Harding, 1991; Keller, 1985).

Some feminist voices emphasizing the differences between males and females have claimed that the qualities of females are better than those of males. Professor of gender studies, Carol Gilligan (1982) described women's moral reasoning to be dominated by an "ethic of care" as compared to men's "ethic of rights". While some feminist critics of science, like the philosopher and professor of education and women's studies Sandra Harding (1993), have argued that females, due to their underprivileged position in many societies, are capable of undertaking more objective observations of the world, others like the Indian physicist Vandana Shiva (2001) claim that a feminine science would be more socially responsible and more capable of advancing a more democratic and environmentally responsible science. Sue Rosser, who is well known both in feminist critique of biology and feminist pedagogy claims that females apply different research methods in their approach to science and would therefore advance a more socially responsible science (Rosser, 1990). Using examples from research carried out from a number of female scientists, she has created a set of descriptions she believes characterizes women's ways of engaging in science. The perspectives she is a proponent for have gained substantial critique from other feminist critics of science.

While most of the above mentioned critique has been leveled against the biological sciences, Sandra Harding (1998) has shown how the developments also of physics, chemistry and technology were followed by, and dependent upon, the exploitation of colonies in non-western countries. Evelyn Fox Keller, who is well known for her work of language and metaphoricity in biology (Keller, 1995), at a seminar in Oslo in 2003, argued that more work was needed to uncover sexist metaphors also in sciences other than biology (Keller 2003).

While several feminist critics have identified masculine biases in scientific inquiry, some have also proposed alternatives to how science could be developed to accommodate androcentric bias. Ruth Bleier (1923-88) was one of the leading feminist biologists and medical doctors who worked on developing critiques of sexist assumptions in science. In her book "Feminist Approaches to Science" (Bleier, 1986) summarized some characteristics of what she calls a feminist science: "Feminist science, being a better science, recognizes the true complexity of nature and of each individual 
human nature. It constantly resists efforts to reduce explanations of complex phenomena to single causes and to strip human behaviors and characteristics of the social and political contexts within and from which they developed" (ibid., p. 16).

Through her "standpoint methodology" Harding has developed a way for the researcher to become conscious of her/his own role as a researcher. She argues that if science is ever to increase its level of objectivity, scientists must recognize and acknowledge the social forces that shape their beliefs (Harding, 1991). The standpoint methodology starts out by including and reflecting on the situatedness of the researcher in order to make visible the genderedness of the knowledge (Harding, 1993; Rustad, 1996). This, according to Harding, is called "strong objectivity".

Harding argues that the standpoint of the researcher will always impact upon knowledge production. Initiatives aiming at increasing female participation in science hence need to be based on the assumption that female scientists would contribute to science in different and better ways than male scientists, and challenge the androcentricm inherent in science:

Should feminism want women to have equality with the men of their respective races and classes without challenging race and class exploitation within science? Should feminism want women, too, to do research that it is only reasonable to predict that will be used by the military or to increase profit? What is progressive about mounting heroic campaigns to "add women and gender" to the social structure and subject matters of the sciences without questioning the legitimacy of science's social hierarchy and politically agendas more generally?

(Harding, 1992, p. 59)

Although the understandings of what causes these gender differences in males' and females' approach to science varies a great deal between difference feminists, they all tend to put an emphasis on the importance of acknowledging and valuing differences between males and females.

In a science education reform program operating under the premises that males and females are different and that females might even be able to contribute in a special way to science, I would expect it to be important to encourage and acknowledge the differences between the sexes. Within such initiatives girls should be encouraged to value, appreciate and develop their own experiences and interests. Teachers operating within this position should therefore pay extra attention and be aware of research documenting differences in girls' and boys' approaches to and interest in science education. In a "difference feminist" science classroom the teacher would be expected to pay extra attention to females and make sure that their special interests and needs are followed up on the girls' own premises. Organizing strategies such as groups divided by sex, single sex schools etc could be applied according to research on girls' interests and particular ways of learning.

A science education based on the assumption that females and males have a different approach to science, and hence contribute differently to the development of scientific knowledge, would be expected to pay extra attention to girls' common interests. It would also be expected that such a science education would incorporate scientific knowledge developed by women. In such science education initiatives, it would also be important to show examples of how scientific knowledge is influenced by its developers. Science education operating under an understanding of males and females as different would therefore be political in the sense that it would focus on visualising how the oppression of, and discrimination against, women have hampered their opportunities to contribute to the development of scientific knowledge. I would label a science education that acknowledges the differences between males and females and is designed mainly in order to accommodate females, a "female friendly science education". The characteristics suggested of such an education are also presented in Table 1. 


\section{Alternative 3: The differences in science engagement among pupils of the same sex are as important as the differences between the two sexes.}

The third alternative I will discuss as to how sex/gender might impact on how pupils engage in science education, is inspired by ideas expressed by postmodern feminists. Feminist thinkers informed by postmodernism have challenged the belief that women are united by biological sex and have asserted that the "category of women" is neither natural, nor essential, but socially constructed (McPherson, 2000). I understand several science educators who currently write on the topic of feminist science education (Barton, 1998; Brickhouse, Lowery \& Schultz, 2000; Brickhouse, 2001; Howes, 2002) to be inspired by postmodern feminism.

Difference feminists have been criticized by postmodern feminists for treating all women alike. They argue that by treating women as one single group, all the voices that exist among different women will not be heard. Women are, according to postmodern feminist thinkers, not one identical group. They do not have one identical story to tell. Within the group of women there are huge differences. According to postmodern theories the standpoint of the researcher as a subject and all other subjects differ from each other. The knowledge that can be achieved about the world is therefore of an individual character and contains no universal truths (Rustad, 1996). All women do hence not view the world in the same way.

An influential contributor to feminist critique of science within a postmodern position is the NorthAmerican biologist and historian of science, Donna Haraway. Haraway (2003) argues against the view that there are some positions that are more epistemologically privileged than others. Her alternative to Harding's "standpoint methodology" is the theory of "situated knowledge". According to the theory of situated knowledge all knowledge is situated and no position is more privileged than others are when it comes to viewing the world. Haraway argues that nobody, no matter of being oppressed or oppressors, men or women, can see the world more clearly than others can. We can only see the world from our personal perspective, and hence all knowledge is situated.

Haraway hence argues that neither men nor women are in a position to describe the world on any other's behalf. She argues that researchers claiming to be able to conduct universal and objective knowledge conduct what she labels the "God-trick". By this she means that they try to exclude their own position and thereby biased basis for research, in order to be able to conduct neutral observations. This "view from nowhere" is, according to Haraway, methodologically impossible (Haraway, 1991).

Haraway does, however, warn against a total relativist view of science (Haraway, 2003). According to Haraway, all stories about the world are not equally valuable. Scientific research thus has a powerful potential to tell good stories about the natural world. There is, however, no stories that represent the only truth. All stories, including scientific stories, are functions of politics and the situatedness of the researcher. Haraway argues that although not all stories about the world are equally valuable, several stories are better than one (Haraway, 1989).

In spite of Haraway's critique of natural science, she argues for the importance of "critique from within". She criticises feminists for being critical of science without knowing the field from the inside. Haraway wants change and she wants more stories to be heard. She therefore promotes a higher representation of females within fields such as science and technology as this will bring new and varied perspectives to the field (ibid.).

Because women are not epistemologically privileged compared to men, the reason for recruiting more girls to science would not, according to Haraway, be that they would produce better knowledge than men would. The reason for more women to be involved in science would be that many stories would not be heard if women did not have the possibility of telling their scientific story. 
Gaining access to the world, the natural as well as the social world, is according to Haraway, about "the power to see" (Haraway, 1991, p. 188). By excluding women from science the power to see would be in the hands of men. This power to see should not be reserved men.

I would expect science education reform programs inspired by postmodern feminist ideas to challenge the idea that female and male pupils are united by biological sex. Science education initiatives acknowledging the difference between all individuals would be expected to encourage all pupils, regardless of their sex, to value their own experiences and interests and make them relevant to the learning of science. Gender reform programs, operating under a postmodern feminist understanding, would be expected to enforce an increased awareness of marginalised groups irrespective of their sex. It should not be taken for granted that pupils have the same preferences and needs because they have the same sex. Single sex school settings would therefore not be adapted in schools inspired by postmodern feminism.

Science education reform programs operating under this understanding of gender and science might explore differences in interest found among pupils of the same sex and develop teaching materials to accommodate such a broad variety of interests. A teacher operating in a postmodern feminist classroom would be expected to be cautious about the varieties in interests and abilities that exist among pupils in the classroom without separating them into categories based on their sex. Groups should rather be developed based on the pupils' individual interests and needs.

A science curriculum based on this understanding would be expected to put much emphasis on visualizing the social, political, cultural and psychological dimensions of science. Science should not be presented as a fixed body of knowledge, but as knowledge that is continuously developed, challenged and changed. Teachers should visualize how all scientific knowledge is constructed and contextualized and how researchers are all influenced by the time in which they live. Pupils and the rest of the public society should be informed about the social, political and gendered assumptions that underpin knowledge production and how social context shapes all knowledge. Pupils should be encouraged to look for hidden assumptions in scientific knowledge and make them explicit. Pupils in a postmodern feminist science classroom should also be encouraged to be explicit about what assumptions they make when making their own statements. Science reform programs based on an understanding that all knowledge is contextualised, should be committed to helping pupils to see various approaches to the same problem and have them realize that there is often more than one single correct answer, also within science.

A science education that is designed in order to accommodate various interests and abilities without assuming that such varieties are a result of having different sex, I would label a "gender sensitive" science education. The suggested characteristics of a gender sensitive science education are outlined in Table 1.

In table 1 I present what I suggest as implications for science education of the three understandings described above. The consequences I see of the different positions for the teaching of the nature of science are in this table written in Italics.

\section{CRITIQUE OF THE DIFFERENT APPROACHES}

In this article, I have tried to visualize that the three approaches to gender equity in science education labeled "gender neutral", "female friendly" and "gender sensitive" can in fact be seen to represent very different understandings of why females are underrepresented in science and thus represent different approaches to secure gender equity in science education. 
Table 1: Suggested implications of equality feminism, difference feminism and postmodern feminism on science education.

\begin{tabular}{|c|c|c|c|}
\hline & Curriculum & Educational material & Teacher development \\
\hline $\begin{array}{l}\begin{array}{l}\text { Equality } \\
\text { feminism }\end{array} \\
\qquad \downarrow \\
\text { Gender } \\
\text { neutral } \\
\text { science } \\
\text { education }\end{array}$ & $\begin{array}{l}\text { - Curriculum should } \\
\text { be gender neutral } \\
\text { and hence be } \\
\text { equally relevant } \\
\text { to both boys and } \\
\text { girls }\end{array}$ & $\begin{array}{l}\text { - Develop gender neutral } \\
\text { education materials either } \\
\text { through: } \\
\text { - Equal number of the } \\
\text { words "he" and "she", } \\
\text { and equal number of } \\
\text { illustrations showing } \\
\text { males and females, or } \\
\text { - Remove all references } \\
\text { to sex, or } \\
\text { - Portray males and } \\
\text { females in untraditional } \\
\text { gender roles }\end{array}$ & $\begin{array}{l}\text { - Teachers should be sensitised not to } \\
\text { discriminate against girls } \\
\text { - Teachers should give equal } \\
\text { attention to girls and boys in class } \\
\text { - Teachers must avoid saying } \\
\text { anything that could be understood } \\
\text { as discriminatory to girls } \\
\text { - Preferably there should be an } \\
\text { equal number of female and male } \\
\text { science teachers } \\
\text { - Teachers must make sure } \\
\text { that girls are given equal } \\
\text { responsibilities in the lab }\end{array}$ \\
\hline $\begin{array}{l}\text { Difference } \\
\text { feminism } \\
\qquad \downarrow \\
\text { Female } \\
\text { friendly } \\
\text { science } \\
\text { education }\end{array}$ & $\begin{array}{l}\text { - Curriculum should } \\
\text { be developed to } \\
\text { accommodate } \\
\text { girls } \\
\text { - Build on research } \\
\text { regarding how } \\
\text { girls learn in } \\
\text { science education } \\
\text { - Be responsive to } \\
\text { feminist critique } \\
\text { of science and } \\
\text { incorporate the } \\
\text { contributions of } \\
\text { women and other } \\
\text { oppressed groups }\end{array}$ & $\begin{array}{l}\text { - Teaching materials } \\
\text { should be female friendly: } \\
\text { - Build on girls' } \\
\text { special interests and } \\
\text { experiences } \\
\text { - Incorporate scientific } \\
\text { knowledge developed } \\
\text { by females and } \\
\text { oppressed } \\
\text { - Show examples } \\
\text { of how scientific } \\
\text { knowledge is biased } \\
\text { by its developers } \\
\text { - Be political in terms } \\
\text { of visualising the } \\
\text { oppression of females } \\
\text { and non western } \\
\text { people }\end{array}$ & $\begin{array}{l}\text {-Teachers should be responsive to } \\
\text { girls special interests, and sensitised } \\
\text { on how girls learn: } \\
\text { - Teach in small groups } \\
\text { - Develop a non-competitive } \\
\text { environment in science class } \\
\text { - Focus on health / body and personal } \\
\text { development whenever possible } \\
\text { - Link science education to girls' out } \\
\text { of school experiences } \\
\text { - Link science education to societal / } \\
\text { environmental issues } \\
\text { - Visualise the masculine bias in } \\
\text { scientific knowledge and priorities } \\
\text { - Visualise the special contributions of } \\
\text { females to science } \\
\text { - Pay extra attention to females in } \\
\text { class } \\
\text { - Separate into girls / boys groups } \\
\text { - Separate schools for girls /boys }\end{array}$ \\
\hline
\end{tabular}

Table continues next side 


\begin{tabular}{|c|c|c|c|}
\hline & Curriculum & Educational material & Teacher development \\
\hline $\begin{array}{l}\text { Post } \\
\text { modern } \\
\text { feminism } \\
\quad \downarrow\end{array}$ & $\begin{array}{l}\text { - Curriculum } \\
\text { should be } \\
\text { developed to } \\
\text { accommodate a } \\
\text { broad variety of } \\
\text { interests } \\
\text { - Curriculum } \\
\text { should visualise } \\
\text { the social, } \\
\text { political and } \\
\text { psychological } \\
\text { dimensions of } \\
\text { science } \\
\text { - Curriculum } \\
\text { should } \\
\text { incorporate } \\
\text { other knowledge } \\
\text { systems }\end{array}$ & $\begin{array}{l}\text { - Teaching materials should } \\
\text { be gender- sensitive: } \\
\text { - Teaching material should } \\
\text { reflect differences in interest } \\
\text { in science } \\
\text { - Teaching materials should } \\
\text { visualise the relations } \\
\text { between science and society } \\
\text { and how social and political } \\
\text { factors impact science } \\
\text { - Teaching materials should } \\
\text { include science developed by } \\
\text { minorities and other cultures } \\
\text { and visualise the differences } \\
\text { between different types of } \\
\text { scientific inquiry }\end{array}$ & $\begin{array}{l}\text { - Teachers should be responsive to } \\
\text { the different perspectives of all pupils } \\
\text { irrespectively of their sex } \\
\text { - Teachers should build on pupils' } \\
\text { experiences irrespectively of their sex/ } \\
\text { apply constructivist teaching methods } \\
\text { - Teachers should visualise that } \\
\text { scientific knowledge is constructed by } \\
\text { human beings and hence influenced by } \\
\text { its creators } \\
\text { - Teachers should acknowledge that } \\
\text { all pupils are different and that great } \\
\text { differences in interests exist also within } \\
\text { groups of pupils of the same sex } \\
\text { - Teachers should introduce questions } \\
\text { of sex, race and class when it is } \\
\text { relevant } \\
\text { - Teachers should not divide pupils into } \\
\text { groups based on sex, but rather on } \\
\text { interests }\end{array}$ \\
\hline
\end{tabular}

All the above understandings of how science education might be changed to accommodate gender differences in science have been criticised within science education literature. What I have labelled "gender neutral" science education has been criticized for building on the assumption that it is possible to produce objective knowledge through scientific inquiry (Kenway \& Gough, 1998). It has also been criticised for not challenging the oppressive and discriminatory practices within scientific inquiry (Harding, 1992). Eisenhart and Finkel (2001) claim that the types of initiatives following from a gender neutral science education, what they call "compensatory strategies" treat disadvantaged persons according to their special needs, but only with the aim of enabling them to measure up to a standard already set by the advantaged. As Howes (2002, p. 23) puts it: "This approach assumes that if women were to think, behave, learn, and work more like male scientists, the problem of women in science would be solved".

Another problem with a gender neutral science education could be that it can easily represent a false picture of reality. Most societies are not gender neutral. Particularly in traditional societies, males and females do have very distinct roles to play. It is therefore difficult to understand how the key to increased gender equity in science could be to reflect a gender neutral situation when most societies are in reality strongly gendered.

Gender and science education reform programs which build on an understanding of males and females as different in their engagement in science would be expected to pay close attention to research trying to document such sex differences. A female friendly science education would then be expected to be designed with the purpose of appreciating and accommodating these differences. There is, however, limited evidence for the existence of such differences. Brickhouse et al. (2000) accuse female friendly science education of reinforcing stereotyped images of females. 
An additional drawback to a female friendly science education could be the effect such an education might have on boys. A science education designed to accommodate pupils on the basis of their sex could easily fail to stimulate and assist boys who experience problems in their learning of science.

Gender sensitive science education is based on the assumption that the variations between pupils of the same sex might be more important than differences between pupils with opposite sex. Such an education would acknowledge the existence of masculine and feminine pupils, but not take for granted that masculinity and femininity necessarily are determined by a person's biological sex.

The implications outlined here for what image of the nature of science that would follow from a postmodern science education might be problematic for science educators to accept. The assumption that all knowledge is contextualised and marked by the fingerprint of the scientists, contests the status of scientific inquiry as a suitable method to obtain objective knowledge about the natural world. Science education initiatives grounded in such postmodern assumptions would therefore require major changes to how science is currently being taught in most science classrooms around the globe. Several science educators might even argue that a postmodern science education is a contradiction in terms.

\section{SUMMING UP: WHICH APPROACH SHOULD GENDER INITIATIVES CHOOSE?}

As I have shown the three approaches that are described can be seen to represent quite different types of initiatives to increase gender equity in science education. All the three approaches do, however, have their weaknesses. The purpose of clarifying the different approaches in this article has not been to recommend one approach over the other, but to show that actions that are commonly recommended as suited to increase gender equity should be analyzed according to what perception they reflect of what role gender/sex plays for pupils engagement in science education. When planning new initiatives to increase gender equity in science education, I argue that regardless of which of the three approaches one considers to be best suited to increase gender equity, it would strengthen gender initiatives to develop a common understanding of what assumptions that underpin the approach one has actually chosen. It is unlikely that gender initiatives will be totally consistent in terms of what approach they operate within. Clarifying and describing the characteristics of the different ideal types might, however, enable initiatives to become more conscious about their own perception of how girls and boys engage in science education and thereby enable such initiatives to plan more consistent actions to increase gender equity in science education.

\section{REFERENCES}

Barton, A. C. (1998). Feminist science education. New York: Teachers College Press.

Bleier, R. (Ed.) (1986). Feminist approaches to science. New York: Pergamon.

Brickhouse, N. W. (2001). Embodying science: a feminist perspective on learning. Journal of Research in Science Teaching, 38 (3), 282-295.

Brickhouse, N. W., Lowery, P. \& Schultz, K. (2000). What kind of a girl does science? The construction of school science identities. Journal of Research in Science Teaching, 37 (5), 441-458.

Eisenhart, M.A. \& Finkel, E. (2001). Women need (still) not apply. In M. Lederman \& I. Bartsch (Eds.): The gender and science reader (pp. 13-23). London and New York: Routledge.

Franklin, S. (2000). Science. In L. Code (Ed.): Encyclopedia of feminist theories. London: Routledge.

Gilligan, C. (1982). In a different voice. Boston: Harvard University Press.

Haraway, D. (1989). Primate visions. Gender, race and nature in the world of modern science. London and New York: Verso. 
Haraway, D. (1991). Simians, cyborgs and women: the reinvention of nature. London: Free Associations Books.

Haraway, D. (2003). Situated knowledges: the science question in feminism and the privilege of partial perspective. In C.R. McCann \& S-K. Kim (Eds.): Feminist theory reader. Local and global perspectives (pp. 391-403). (Original work published in 1988).

Harding, S. (1986). The science question in feminism. Buckingham: Open University Press.

Harding, S. (1991). Who's science, who's knowledge. Thinking from women's lives. Ithaca, New York: Cornell University Press.

Harding, S. (1992). How the women's movement benefits science: Two views. In G. Kirkup, \& L. S. Keller (Eds.): Inventing women. Science, technology and gender (pp. 57-72). Cambridge: Polity Press.

Harding, S. (1993). Rethinking standpoint epistemology: What is "strong objectivity"? In L. Alcoff \& E. Potter (Eds.): Feminist epistemologies (pp. 49-82). New York and London: Routledge.

Harding, S. (1998). Is science multicultural? Postcolonialisms, feminisms, and epistemologies. Bloomington and Indianapolis: Indiana University Press.

Howes, E. V. (2002). Connecting girls and science. Constructivism, feminism, and education reform. New York: Teachers College Press.

Keller, E. F. (1985). Reflections on gender and science. New Haven and London: Yale University Press.

Keller, E. F. (1987). Feminism and science. In S. Harding \& J. F. O'Barr (Eds.): Sex and scientific inquiry (pp. 233-246). Chicago: University of Chicago Press.

Keller, E. F. (1995). Refiguring Life: Metaphors of Twentieth Century Biology. New York, Columbia University Press.

Keller, E. F. (2003). Understanding nature: gender and biology. Presentation made at the University of Oslo June 6, 2003.

Kenway, J. \& Gough, A. (1998). Gender and science education in schools: A review "with attitude". Studies in Science Education, 31, 1-30.

McPherson, K. (2000). First-wave/second-wave feminism. In L. Code (Ed.): Encylopedia of feminist theories (pp. 208-210). London: Routledge.

Nash, K. (2000). Equality and difference. In L. Code (Ed.): Encylopedia of feminist theories (pp. 174-176). London: Routledge.

Rosser, S. V. (1990). Female friendly science. Applying women's studies methods and theories to attract students. New York: Pergamon Press.

Rustad, L. M. (1996). Posisjonering versus gudetriks: Et feministisk epistemologi prosjekt, (Positioning versus God trick: a feminist epistemology project ). Skriftserie Senter for Kvinneforskning, 4. Trondheim: NTNU.

Scantelbury, K. (1998). An untold story: Gender, constructivism and science education. In W.W. Cobern (Ed.), Socio-cultural perspectives in science education (pp. 99-120). Dordrecht, Netherland: Kluwer Academic Publishers.

Shiva, V. (2001). Democratizing biology. Reinventing biology from a feminist, ecological and Third World perspective. In M. Lederman \& I. Bartsch (Eds.): The gender and science reader (pp. 447-465). London and New York: Routledge.

Shulman, B. J. (2001). Implications of feminist critique of science for the teaching of mathematics and science. Journal of Women and Minorities in Science and Engineering, 1, 1-15.

Sinnes, A. T. (2005). Approaches to Gender Equity in Science Education. Two initiatives in subSaharan Africa seen through a lens derived from feminist critique of science. Dissertation for the degree of dr.scient., University of Oslo. Oslo: Unipub.

Tong, R. (2000). Cultural feminism. In L. Code (Ed.): Encylopedia of feminist theories (pp. 113115). London: Routledge.

Whatley, M. (1988). Photographic images of blacks in sexuality texts. Curriculum Inquiry, 18 (2), 137-155.

Ødegaard, M. (2001): The Drama of Science Education. How public understanding of biotechnology and drama as a learning activity may enhance a critical and inclusive science education. Dissertation for the degree of dr.scient., University of Oslo. Oslo: Unipub. 